\title{
Productive performance of cowpea-radish intercropping under different amounts of rooster tree biomass incorporated into the soil
}

\author{
Maria F. S. Pereira ${ }^{1}$, Francisco Bezerra Neto ${ }^{1}$, Frederico S. T. Pontes ${ }^{2}$, \\ Paulo C. F. Linhares ${ }^{1}$, Maiele L. da Silva ${ }^{3} \&$ Ítalo N. Silva ${ }^{1}$ \\ ${ }^{1}$ Universidade Federal Rural do Semi-Árido/Departamento de Ciências Vegetais. Mossoró, RN. E-mail: mf.agro@yahoo.com.br; bezerra@ufersa.edu.br \\ (Corresponding author); paulolinhares@ufersa.edu.br; italonunessilva@gmail.com \\ ${ }^{2}$ Universidade Federal Rural do Semi-Árido/Departamento de Agrotecnologia e Ciências Sociais. Mossoró, RN. E-mail: frederico@ufersa.edu.br \\ ${ }^{3}$ Universidade Estadual de Mato Grosso do Sul/Unidade de Aquidauana. Aquidauana, MS. E-mail: maiele_engenharia@yahoo.com.br
}

\section{Key words:}

Vigna unguiculata

Raphanus sativu

Calotropis procera

spontaneous species

intercropping

\begin{abstract}
A B S T R A C T
Intercropping systems of cowpea with radish are beginning to be deployed in the semiarid region of Rio Grande do Norte state. The great challenge is to know whether or not there is productive efficiency in these systems when fertilized with organic matter produced by spontaneous species from the 'Caatinga' biome. Thus, the aim of this study was to evaluate the productive performance of cowpea-radish intercropping systems under different amounts of rooster tree biomass incorporated into the soil. The study was conducted at the experimental farm Rafael Fernandes, rural zone of Mossoró, RN, in the period from June to September 2013, in an experimental design of randomized blocks with four treatments and five replicates. The treatments consisted of the following amounts of rooster tree biomass incorporated into the soil (10,25, 40 and $55 \mathrm{tha}^{-1}$ on a dry weight basis). The best productive performance of the cowpea-radish intercrop was obtained when the rooster tree biomass amount of $50.01 \mathrm{tha}^{-1}$ was incorporated to the soil. The use of rooster tree biomass as green manure is agronomically viable in intercropped systems of cowpea-radish.
\end{abstract}

\section{Palavras-chave:} Vigna unguiculata Raphanus sativus Calotropis procera espécie espontânea associação de culturas

\section{Desempenho produtivo do consórcio caupi-rabanete sob diferentes quantidades de biomassa de flor-de-seda incorporadas no solo}

\section{R E S U M O}

Sistemas consorciados de caupi com rabanete estão começando a ser implantados no semiárido do Rio Grande do Norte. O grande desafio é saber se existe ou não eficiência produtiva nesses sistemas quando adubados com matéria orgânica produzida por espécies espontâneas do bioma Caatinga. Assim, o objetivo deste estudo foi avaliar o desempenho produtivo de sistemas consorciados de caupi-rabanete sob diferentes quantidades de biomassa de flor-de-seda incorporada ao solo. O estudo foi realizado na Fazenda Experimental Rafael Fernandes, zona rural de Mossoró, RN, no período junho-setembro de 2013, em um delineamento experimental de blocos casualizados, com quatro tratamentos e cinco repetições. Os tratamentos consistiram das seguintes quantidades de biomassa de flor-de-seda incorporada ao solo (10, 25, 40 e $55 \mathrm{t} \mathrm{ha}^{-1} \mathrm{em}$ base seca). O melhor desempenho produtivo do consórcio caupi-rabanete foi obtido quando a quantidade de biomassa de flor-de-seda de 50,01 t ha ${ }^{-1}$ foi incorporada ao solo. O uso da espécie flor-de-seda do bioma Caatinga como adubo verde é agronomicamente viável em sistemas consorciados de caupi-rabanete. 


\section{INTRODUCTION}

The intercropping of cowpea [Vigna unguiculata L. (Walp.)] with a tuberous species is beginning to be practiced in the semiarid region of northeastern Brazil, including with the radish crop. It is a major leguminous species of economic and nutritional value grown in the region that can complement an intercropped system with the radish crop because it has different architecture and root system. This legume is very consumed in the form of pod, where their immature beans, known as green beans, constitute the raw material for a range of regional dishes, besides being used as green manure (Santos et al., 2009).

The radish (Raphanus sativus L.), in turn, is a tuberous vegetable crop of fast cycle (about 35 days), rich in phosphorus, calcium, thiamine and riboflavin (Filgueira, 2008), whose cultivation is growing in the semiarid region of the Brazilian northeast, where there are approximately 352 production units that grow this crop (Batista et al., 2013), most of which are in sole crop.

In the production systems with tuberous vegetable crops (including radish), cattle manure has been the traditional raw material used by the producers. Thus, the use of alternative raw materials, such as green manure, can allow a substitution of the quantities of cattle manure to be applied, and contribute to restoring the $\mathrm{N}$ reserves in the soil (Castro et al., 2004). It is known, therefore, that the green manures increase the organic matter content in the soil, improve the availability of nutrients, and reduce the contents of aluminum and mobilization of nutrients (Kumar \& Shivay, 2007).

Scientific studies with spontaneous species of the Caatinga biome such as the rooster tree [(Calotropis procera (Ait.) R. Br.] and hairy woodrose (Merremia aegyptia L.) are being performed aiming to successfully use these species as green manure in tuberous and broadleaf vegetable crops in the semiarid region of northeast Brazil (Linhares et al., 2009; Bezerra Neto et al., 2011; Goés et al., 2014; Souza et al., 2015).

Thus, the aim of this study was to evaluate the productive performance of cowpea-radish intercropping systems under different amounts of rooster tree biomass incorporated into the soil.

\section{Material e Methods}

The study was conducted at the Experimental Farm Rafael Fernandes, belonging to the Federal Rural University of the Semi-Arid (UFERSA), Mossoró, RN, Brazil, in the period from June to September 2013. The climate of Mossoró is of the BShw group, being characterized as tropical and semiarid (Batista et al., 2013).

During the experimental period, the rainfall was $0 \mathrm{~mm}$; the maximum, mean, and minimum temperatures were 31,27 and $25{ }^{\circ} \mathrm{C}$, respectively; relative humidity $66 \%$ and radiation $918 \mathrm{~kJ} \mathrm{~m}^{-2}$.

The soil of the experimental area was classified as dystrophic argisolic Alfisol (Oliveira et al., 2015). Prior to the experiment, 50 samples were taken in this area and subsequently mixed in order to obtain a composite sample, which was processed and analyzed, whose results were as follows: $\mathrm{pH}$ (water) =7.09;
$\mathrm{OM}=11.5 \mathrm{mg} \mathrm{dm}{ }^{-3} ; \mathrm{N}=0.04 \mathrm{~g} \mathrm{~kg}^{-1} ; \mathrm{P}=15.14 \mathrm{mg} \mathrm{kg}^{-1} ; \mathrm{K}=$ $50.5 \mathrm{mg} \mathrm{dm}{ }^{-3} ; \mathrm{Na}=4.1 \mathrm{mg} \mathrm{dm}^{-3} ; \mathrm{Ca}=1.84 \mathrm{cmol}_{\mathrm{c}} \mathrm{dm}^{-3} ; \mathrm{Mg}=$ $1.39 \mathrm{cmol} \mathrm{dm}_{c}^{-3}$ and CEC $=3.38 \mathrm{cmol} \mathrm{dm}_{\mathrm{c}}^{-3}$.

The experimental design was a randomized block with four treatments and five replicates. The treatments consisted of the following amounts of rooster tree biomass incorporated into the soil $\left(10,25,40\right.$ and $55 \mathrm{t} \mathrm{ha}^{-1}$ on a dry weight basis). Each experimental unit had a total area of $3.60 \mathrm{~m}^{2}(3.00 \times$ $1.20 \mathrm{~m}$ ) with $2.00 \mathrm{~m}^{2}$ of harvest area. The biomass amounts were incorporated into the soil in each treatment 20 days before sowing according to the recommendation of Linhares et al. (2011).

The soil preparation consisted of mechanical cleaning of the area, harrowing and construction of the beds. After this, a soil solarization was performed on the beds with Vulcabrilho Bril Fles 30-micra transparent plastic for 30 days with the aim of combating nematodes and phytoparasites (Silva et al., 2006).

The rooster tree biomass was collected from native vegetation in the urban perimeter of Mossoró-Apodi, ground up into pieces of $2-3 \mathrm{~cm}$ and placed to dry at room temperature until they reach the point of hay, being stored with moisture content of $8.3 \%$. Samples of this green manure were taken randomly for quantification of the nutrient contents, obtaining following results: $15.3 \mathrm{~g} \mathrm{~kg}^{-1} \mathrm{~N} ; 4.0 \mathrm{~g} \mathrm{~kg}^{-1} \mathrm{P} ; 15.7 \mathrm{~g} \mathrm{~kg}^{-1} \mathrm{~K} ; 9.3$ $\mathrm{g} \mathrm{kg}^{-1} \mathrm{Ca} ; 7.03 \mathrm{~g} \mathrm{~kg}^{-1} \mathrm{Mg} ; 4.39 \mathrm{~g} \mathrm{~kg}^{-1} \mathrm{~S}$, and Carbon:Nitrogen ratio of 20:1.

The intercropping systems were established in alternated strips of the component crops in proportion of $50 \%$ of the area for cowpea and $50 \%$ of the area for the radish, where each plot consisted of four rows of alternated cowpea with four radish rows, flanked by two guard rows of cowpea on one side and by two rows of radish on the other side, thereby constituting the side borders. The total area of the plot was $3.6 \mathrm{~m}^{2}$, with a harvest area of $2.00 \mathrm{~m}^{2}$ containing 40 plants of cowpea spaced by $0.25 \mathrm{~m}$ between rows with 10 plants per linear meter and 100 radish plants spaced by $0.25 \mathrm{~m}$ between rows with 25 plants per linear meter. The cowpea cultivar planted was the 'BRS Itaim' and radish was the 'Crimson Giant'.

In each block, a single plot of each vegetable crop was planted with six rows on its ideal population density recommended by research. The cowpea was planted at a spacing of $0.50 \mathrm{~m}$ between rows with 10 plants per meter, providing a density of 200,000 plants ha ${ }^{-1}$ (Freire Filho, 2011) and the radish spaced at $0.20 \times 0.10 \mathrm{~m}$, giving a density of 500,000 plants ha ${ }^{-1}$ (Batista et al., 2013). In all intercropped plots, the same population densities of their sole crops were used.

The sowing of cowpea and radish occurred on 07/19/2013. At seven and ten days after emergence, the thinning was carried out for the cowpea and radish crops, respectively. During the conduction of the research, there were two hand weedings and two irrigations, daily by micro-sprinkler system, with a water depth of about $8 \mathrm{~mm}$, in order to keep the soil moisture between 50 to $70 \%$ of the field capacity, which is an ideal condition for the nitrification process (Meurer, 2007).

The harvest of the radish was carried out 35 days after sowing, and for the cowpea at 65 days. Five harvests were 
performed in the cowpea crop and the last one occurred on $10 / 07 / 2013$. The characteristics evaluated in the radish were: plant height $(\mathrm{cm})$ and diameter of roots (measured using a digital caliper in the transverse direction in 20 units, expressed in $\mathrm{mm}$ ); total and commercial productivities (determined from the fresh mass weight of plant roots of the harvest area, expressed in tha-1); productivity of scrap roots $\left(\mathrm{t} \mathrm{ha}^{-1}\right)$ and dry mass of roots (obtained by a sample of 20 plants and expressed in $\mathrm{t} \mathrm{ha}^{-1}$ ).

For cowpea, the following variables were determined: number of green pods $\mathrm{m}^{-2}$, length of green pods (determined in a random sample of 20 plants of the harvested area marked with satin tape from the first harvest, through a ruler, expressed in $\mathrm{cm}$ ); productivity of green pods (quantified by all pods harvested in the plants of the harvested area, expressed in $t^{\text {ha- }}{ }^{-1}$ ); dry mass of green pods (obtained from a random sample of 20 plants in the harvested area); number of green grains per pod (obtained from a 20-pod sample, randomly chosen in the harvested area of each plot); weight 100 green grains (obtained from the same sample of 20 pods); productivity of green grains (quantified from the amount of green beans obtained of the harvested area of each plot, expressed in $t \mathrm{ha}^{-1}$ ) and dry mass of green grains (obtained with three random samples of 100 green grains, expressed in $\mathrm{tha}^{-1}$ ).

The productive efficiency of intercropping system was determined by means of the score of the canonical variable obtained through bivariate analysis of variance of the commercial productivity of radish and cowpea (green grain) productivity.

Regression analyses were performed for the evaluated characteristics and the response curve fitting procedures between each variable and the amounts of rooster tree incorporated into the soil were carried out according to the procedure used by Silva et al. (2011).

A.

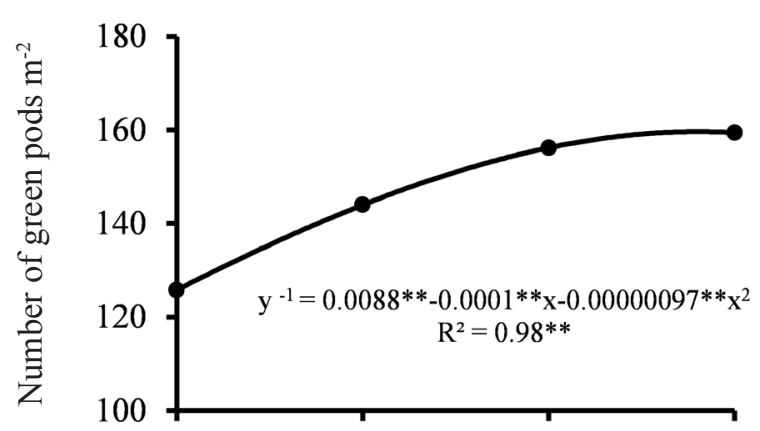

C.

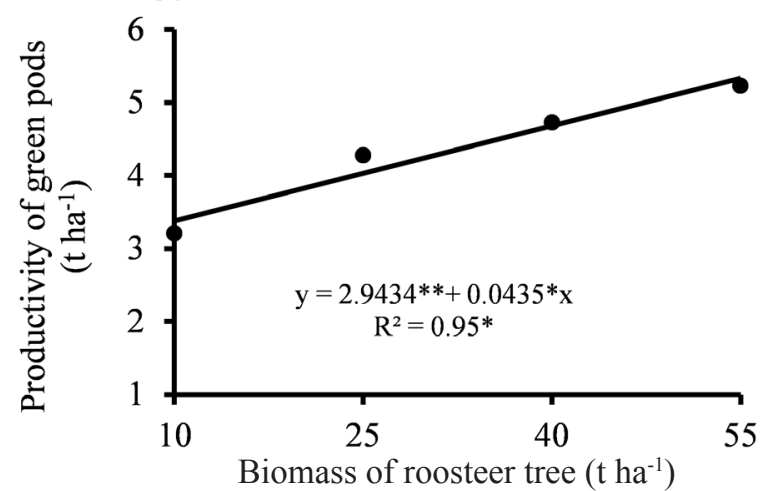

\section{Results AND Discussion}

A quadratic function was recorded for the number of green pods $\mathrm{m}^{-2}$, for the length of the green pods and for the dry mass of the green pods with the increasing amounts of rooster tree, with an increase until the optimized values of $159.6 ; 16.38$ $\mathrm{cm}$; and $1.73 \mathrm{t} \mathrm{ha}^{-1}$ respectively, in the amounts of $51.66 ; 43.53$ and $48.22 \mathrm{t} \mathrm{ha}^{-1}$ of the green manure incorporated into the soil, decreasing then up to the last amount added to the soil (Figures 1A, 1B and 1D).

However, for productivity of green pods, there was an increasing linear behavior, with an increase of $1.96 \mathrm{ha}^{-1}$, between the lowest and the highest amounts of rooster tree, and consequently, not being possible to obtain an optimized value for this variable (Figure 1C).

For the characteristics evaluated in the green grains, a linear function was observed for the number and weight of 100 grains and productivity with the increasing amounts of the green manure, not being possible to obtain an optimized value for these variables (Figures $2 \mathrm{~A}, 2 \mathrm{~B}$ and $2 \mathrm{C}$ ), where the highest values obtained were of $8.5 ; 27.61 \mathrm{~g}$ and $3.60 \mathrm{tha}^{-1}$ with the greatest amount of green manure added to the soil $(55 \mathrm{t}$ $\mathrm{ha}^{-1}$ ), corresponding to an average increase of 1.8 in green grain number, 4.99 in the 100 green grains weight and $1.50 \mathrm{t} \mathrm{ha}^{-1}$ in the green grain productivity of cowpea in relation to the lowest amount incorporated (10.0 $\mathrm{t} \mathrm{ha}^{-1}$ ) (Figures 2A, 2B and 2C).

Regarding the grain size, very important parameter in the market, both internal and external, in the two largest amounts of rooster tree incorporated, the obtained weight of 100 grains was greater than $25 \mathrm{~g}$, and just above the minimum required by the market (Freire Filho et al., 2009).

B.

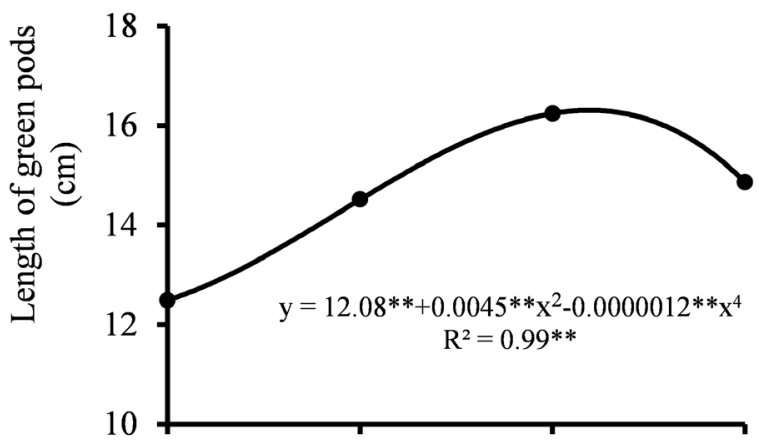

D.

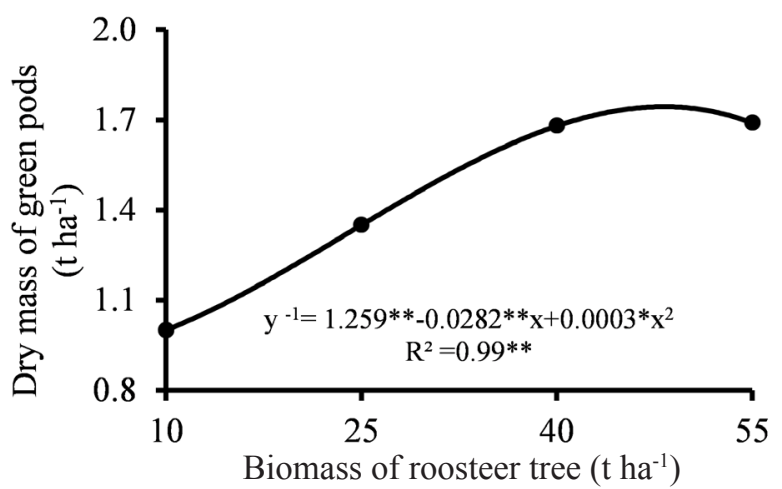

Figure 1. Number of green pods $\mathrm{m}^{-2}(\mathrm{~A})$, length of green pods (B), productivity $(\mathrm{C})$ and dry mass of green pods (D) of cowpea as a function of biomass of rooster tree incorporated into the soil 
A.

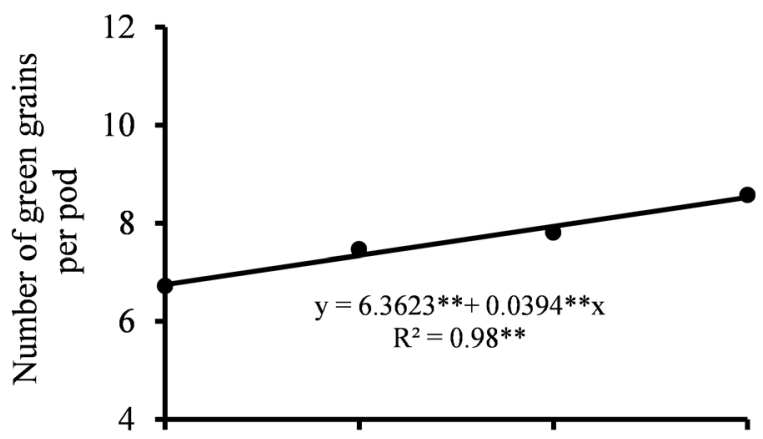

C.

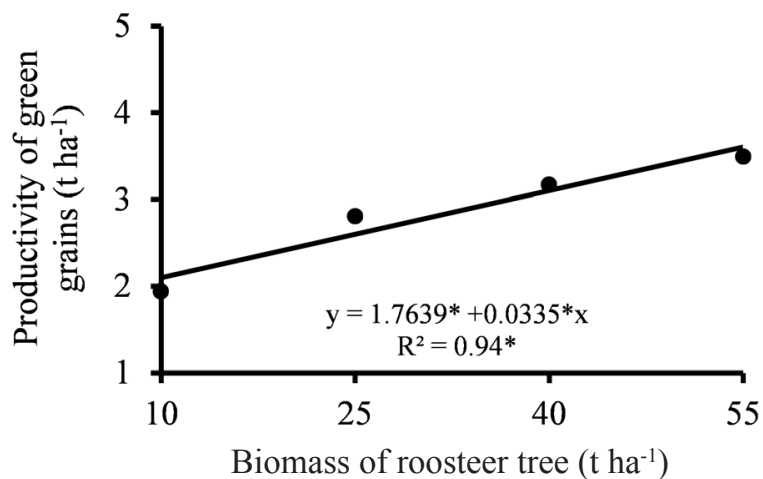

B.

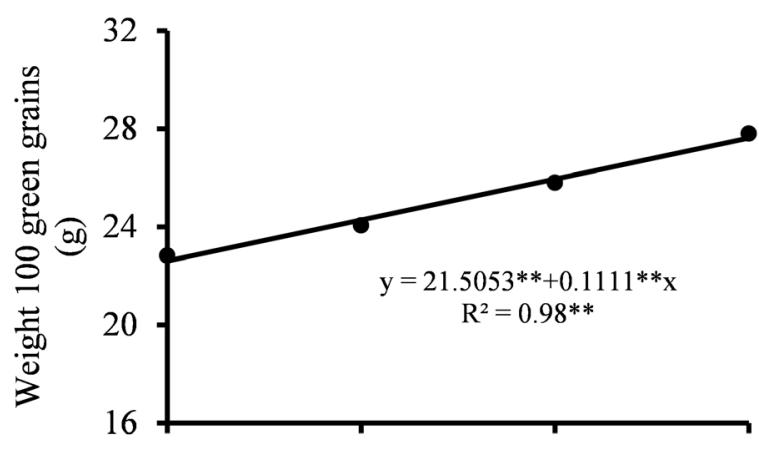

D.

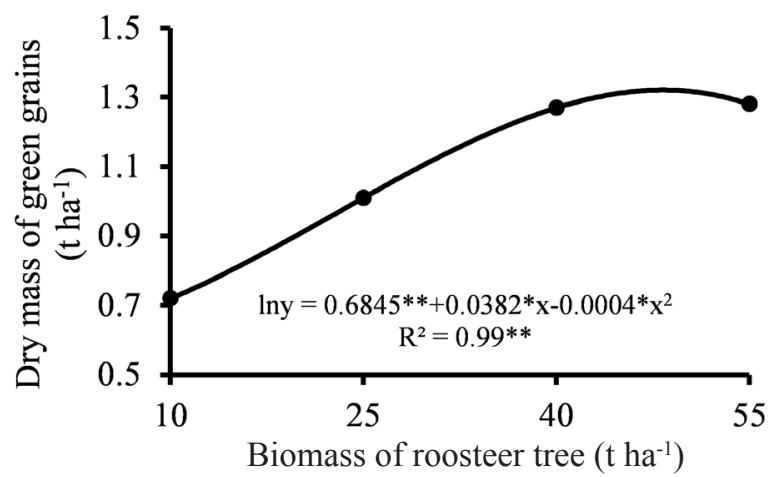

Figure 2. Number of green grains per pod (A), weight of 100 green grains (B), productivity of green grains (C) and dry mass of green grains $(D)$ of cowpea as a function of biomass of rooster tree incorporated into the soil

For dry mass of green grains, a quadratic equation was obtained as a function of the boimass of rooster tree added to the soil, with an increase up to the optimized value of $1.30 \mathrm{t} \mathrm{ha}^{-1}$ in the amount of $49.59 \mathrm{t} \mathrm{ha}^{-1}$ of the green manure incorporated into the soil, decreasing thereafter (Figure 2D).

The optimization of the characteristics evaluated in the pods and in the green grains of cowpea is partly due to higher availability of nutrients released by the increasing amounts of rooster tree incorporated into the soil, but also by the synchrony through which these nutrients are released and absorbed by plants (Fontanétti et al., 2006).

Bezerra Neto et al. (2013b), studying the behavior of the productivity of green grains in the intercropping of cowpea with sugar beet as a function of rooster tree amounts added to the soil, did not achieve optimization of this variable due to the amounts of green manure, registering a behavior similar to that obtained in this research.

For the behavior observed in the equations of the agronomic characteristics assessed in the radish intercropped with cowpea as a function of the biomass of rooster tree incorporated into the soil, a linear function was registered for the plant height (Figures $3 \mathrm{~A}$ ) and a quadratic function for plant diameter, total and commercial productivity of roots, productivity of scrap roots and dry mass of root with the increasing biomass of rooster tree (Figures 3B, 3C, 3D, 3E and 3F).

The highest values for the plant height and dry mass of roots of radish of $23.88 \mathrm{~cm}$ and $0.61 \mathrm{t} \mathrm{ha}^{-1}$, were obtained with the greatest biomass of green manure added to the soil $\left(55 \mathrm{t} \mathrm{ha}^{-1}\right)$, corresponding to a mean increase of $10.29 \mathrm{~cm}$ in plant height and $0.11 \mathrm{tha}^{-1}$ of dry mass of the radish roots in relation to the smallest amount $\left(10.0 \mathrm{t} \mathrm{ha}^{-1}\right)$ (Figures $3 \mathrm{~A}$ and $\left.3 \mathrm{~F}\right)$. These characteristics are strongly influenced by nitrogen, element responsible for leaf expansion and development of the root mass. The concentration of the nitrogen in the manure from rooster tree was $15.5 \mathrm{~g} \mathrm{~kg}^{-1}$, and the increase in their amounts up to the maximum dose of $55.0 \mathrm{t} \mathrm{ha}^{-1}$ was not sufficient for optimizing plant height and dry mass of radish roots.

Linhares et al. (2010) registered an increasing linear behavior for the root dry mass as a function of amounts of hairy woodrose biomass incorporated into the soil, behavior similar to that obtained in this study, with a maximum value of $0.48 \mathrm{t} \mathrm{ha}^{-1}$ reached in larger amount of manure.

For the diameter of plants, total and commercial productivity of roots, and for scrap root productivity, an increase was observed in these traits with the increasing amounts of rooster tree until optimized values of $41.86 \mathrm{~cm}$; 11.64; 10.01 and $1.86 \mathrm{t} \mathrm{ha}^{-1}$ in the amounts of 40.67; 47.97; 49.86 and $29.15 \mathrm{t} \mathrm{ha}^{-1}$ of rooster tree incorporated into the soil, respectively, decreasing then until the largest amount of green manure added to the soil (Figures 3B, 3C, 3D and 3E).

The increasing responses up to the optimization of these variables can be partly assigned to the increasing amounts of rooster tree and the greater availability of nutrients released by this manure, as well as by the synchrony in which these elements are released and absorbed by the plant (Silva et al., 2013). On the other hand, the decreasing responses of these characteristics after the optimal values was due to the Law of the Maximum, where the excess of a nutrient in the soil may cause toxic effect and/or diminish the effectiveness of others, resulting in reduced values of these variables (Almeida et al., 2015). 
A

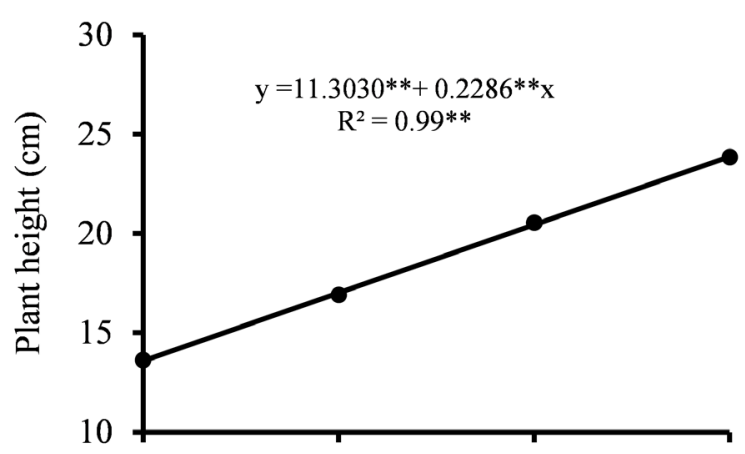

C.

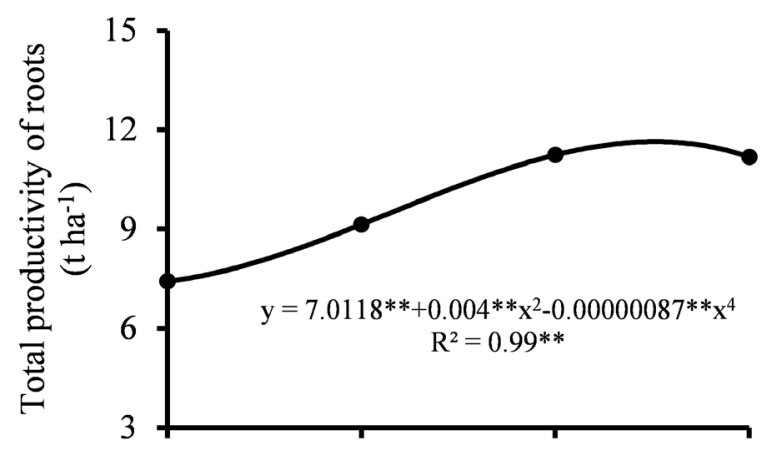

E.

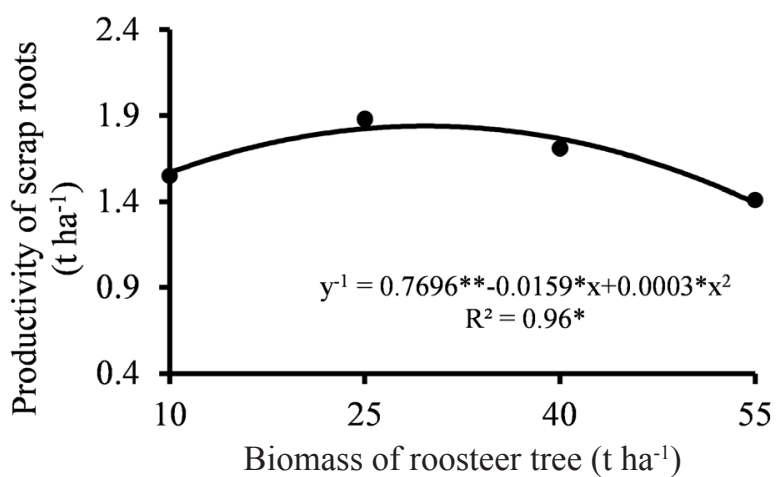

B.

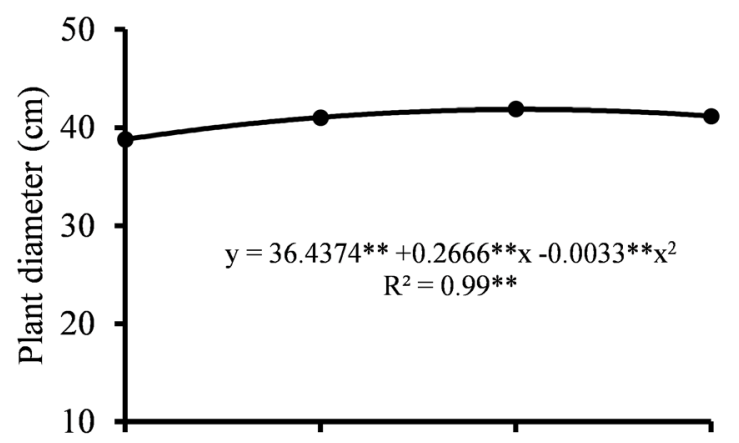

D.

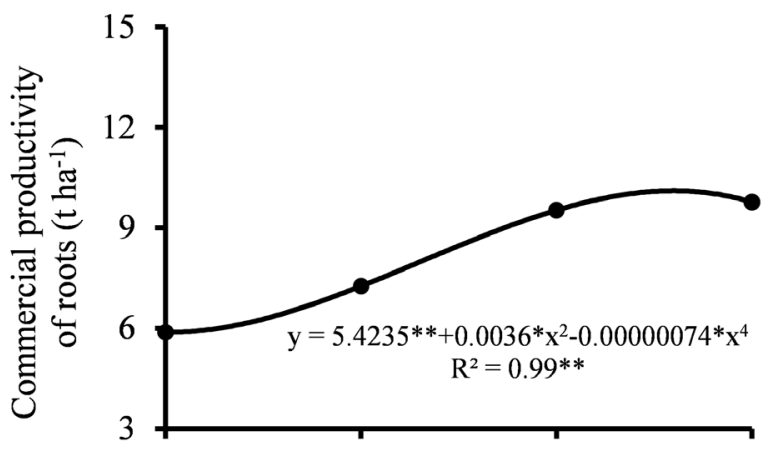

$\mathrm{F}$.

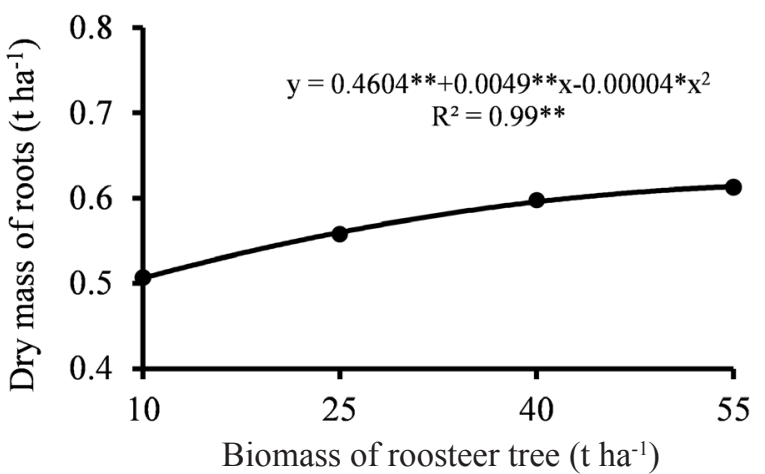

Figure 3. Plant height (A) and diameter (B), total (C) and commercial (D) productivity of roots, productivity of scrap roots $(E)$, and dry mass of roots $(F)$ as a function of amounts of rooster tree incorporated into the soil

Batista et al. (2013), studying the radish manure with three types of spontaneous species of 'Caatinga', hairy woodrose, oneleaf senna and rooster tree, observed an increasing linear behavior for the total and commercial productivity of radish as a function of the amounts of green manure, behavior different to that obtained in this study, which was quadratic, with optimization of these variables. This difference can be explained by the amounts of rooster tree studied by the authors, which ranged from 5.4 to $21 \mathrm{t} \mathrm{ha}^{-1}$, far below that used in this work.

Bezerra Neto et al. (2013b), working with sugar beet intercropped with cowpea, obtained optimization of the commercial productivity of beet as a function of increasing amounts of rooster tree, with the incorporation of $46.84 \mathrm{tha}^{-1}$ green manure, behavior similar to that obtained with radish intercropped with cowpea in the amount of green manure of $49.86 \mathrm{t} \mathrm{ha}^{-1}$. Based on these results, it can be inferred that, when the cowpea is intercropped with a tuberous species of cycle not as long, such as radish and sugarbeet, the amounts of the green manure 'rooster tree' needed to optimize their commercial productivities are in the interval of $47-50 \mathrm{t} \mathrm{ha}^{-1}$ applied to the ground.

In the efficiency of the cowpea and radish intercropping, measured by the score behavior of the canonical variable (Z), a quadratic function was observed for $\mathrm{Z}$ as a function of increasing amounts of rooster tree incorporated into the ground (Figure 4), with an increase in the score of this variable until the amount of $50.01 \mathrm{tha}^{-1}$, at which the maximum value of this variable (10.21 t ha-1 $)$ was observed, decreasing then until the largest amount of the green manure incorporated into the soil (Figure 4).

This result occurred because the intercropping responded very well to green manuring with rooster tree, due to the better use of environmental resources by cowpea and radish plants in the intercropping system, provided by the tested amounts of rooster tree. So, this use has been translated into productive or agronomic efficiency. It is known that green manuring improves the fertility, increases the content of organic matter, reduces erosion rates, increases water retention in the soil, increases the activity of the soil microbiota by increasing the 


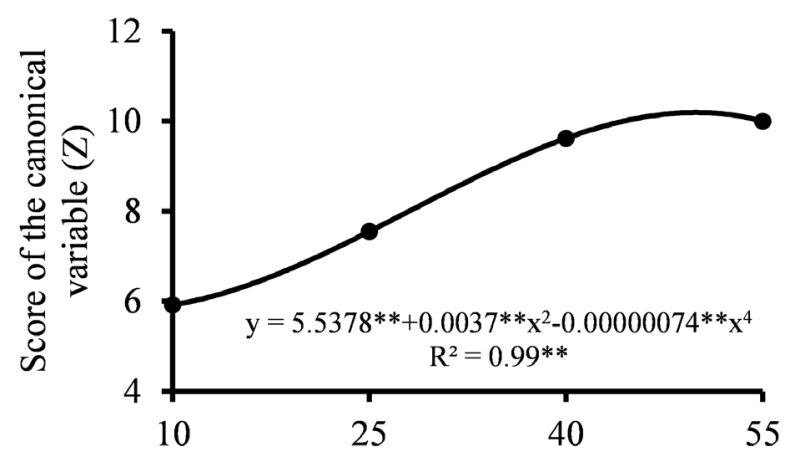

Amounts of roostertree $\left(t \mathrm{tha}^{-1}\right)$

Figure 4. Score of the canonical variable (Z) as a function of amounts of rooster tree incorporated into the soil

availability of nutrients and reduces the amount of invasive plants (Graham \& Haynes, 2006).

Bezerra Neto et al. (2013a), working with the intercropping of cowpea and carrot, obtained optimized score of the canonical variable as a function of increasing amounts of rooster tree, with the addition of $46.00 \mathrm{tha}^{-1}$ of green manure, a behavior similar to that reached with the cowpea intercropped with radish in a slightly larger amount of green manure, 50.01 $\mathrm{t} \mathrm{ha}^{-1}$. Based on these results can be inferred that the use of rooster tree as green manure is agronomically viable in the intercropping of cowpea with radish.

\section{Conclusions}

1. The best productive performance of the cowpea-radish intercrop was obtained when the rooster tree biomass amount of $50.01 \mathrm{t} \mathrm{ha}^{-1}$ was incorporated to the soil.

2. The use of rooster tree biomass as green manure is agronomically viable in intercropped systems of cowpearadish.

\section{ACKNOWLedgement}

Special thanks are due to the Coordination for the Improvement of Higher Education Personnel (CAPES), for the financial support to this research and to the research group that develops technologies for growing vegetables on family farms.

\section{Literature Cited}

Almeida, A. E. S.; Bezerra Neto, F.; Costa, L. R.; Silva, M. L.; Lima, J. S. S.; Barros Júnior, A. P. Eficiência agronômica do consórcio alfacerúcula fertilizado com flor-de-seda. Revista Caatinga, v. 28, p.7985, 2015. http://dx.doi.org/10.1590/1983-21252015v28n309rc

Batista, M. A. V.; Bezerra Neto, F.; Ambrósio, M. M. Q.; Guimarães, L. M. S.; Saraiva, J. P. B.; Silva, M. L. Atributos microbiológicos do solo e produtividade de rabanete influenciados pelo uso de espécies espontâneas. Horticultura Brasileira, v.31, p.587-594, 2013. http://dx.doi.org/10.1590/S0102-05362013000400013

Bezerra Neto, F.; Góes, S. B.; Sá, J. R.; Linhares, P. C. F.; Góes, G. B.; Moreira, J. N. Desempenho agronômico da alface em diferentes quantidades e tempos de decomposição de jitirana verde. Revista Brasileira de Ciências Agrárias, v.6, p.236-242, 2011. http://dx.doi. org/10.5039/agraria.v6i2a977
Bezerra Neto, F.; Silva, M. L.; Vieira, F. A.; Silva, R. C. P. Performance produtiva de cenoura consorciada com caupi-hortaliça sob diferentes quantidades de flor-de-seda. In: Congresso Nacional de Feijão-Caupi, 3, 2013. Anais... Recife: Instituto Agronômico de Pernambuco, 2013a.

Bezerra Neto, F.; Silva, M. L.; Vieira, F. A.; Silva, R. C. P.; Silva, I. N. Consórcio de beterraba com caupi-hortaliça adubado com diferentes quantidades de flor-de-seda. In: Congresso Nacional de Feijão-Caupi, 3, 2013. Anais... Recife: Instituto Agronômico de Pernambuco, 2013b.

Castro, C. M.; Alves, B. J. R.; Almeida, D. L. Adubação verde como fonte de nitrogênio para a cultura da berinjela em sistema orgânico. Pesquisa Agropecuária Brasileira, v.39, p.779-785, 2004.

Filgueira, F. A. R. Novo manual de olericultura: Agrotecnologia moderna na produção e comercialização de hortaliças. Viçosa: UFV, 2008. 421p.

Fontanétti, A.; Carvalho, G. J.; Gomes, L. A. A.; Almeida, K.; Morais, S. R. G.; Teixeira, C. M. Adubação verde na produção orgânica de alface americana e repolho. Horticultura Brasileira, v.24, p.146-150, 2006. http://dx.doi.org/10.1590/S010205362006000200004

Freire Filho, F. R. Feijão-caupi no Brasil: Produção, melhoramento genético, avanços e desafios. Teresina: Embrapa Meio-Norte, 2011. 84p.

Freire Filho, F. R.; Rocha, M. de M.; Ribeiro, V. Q.; Silva, K. J. D. E.; Carvalho, H. W. L.; Cravo, M. S.; Lopes, A. M.; Vilarinho, A. A.; Saboya, R. C. C.; Cavalcante, E. S.; Costa, A. F. da; Alcântara, J. P.; Sittolin, R. C. C. BRS Itaim: Cultivar de feijão-caupi com grãos tipo fradinho. Manual técnico. Teresina: Embrapa Meio-Norte, 2009. 2p.

Goés, S. B.; Sá, J. R.; Duda, G. P.; Bezerra Neto, F.; Silva, M. L.; Linhares, P. C. F. Changes in the $\mathrm{pH}$ and macronutrients in soil fertilized with hairy woodrose in different amounts and times of incorporation. Revista Caatinga, v.27, p.1-10, 2014.

Graham, M. H.; Haines, R. J. Organic matter status and the size, activity and metabolic diversity of the soil microbial community in the row and inter-row of sugar cane under burning a trash retention. Soil Biology \& Biochemistry, v.38, p.21-31, 2006. http:// dx.doi.org/10.1016/j.soilbio.2005.04.011

Kumar, D.; Shivay, Y. S. Green manuring: Benefits, management and constraints. Kurukshetra, v.55, p.12-15, 2007.

Linhares, P. C. F.; Pereira, M. F. S.; Oliveira, B. S.; Henriques, G. P. de S. A. Produtividade de rabanete em sistema orgânico de produção. Revista Verde de Agroecologia e Desenvolvimento Sustentável, v.5, p.94-101, 2010.

Linhares, P. C. F.; Silva, M. L.; Pereira, M. F. S.; Bezerra, A. K. H.; Paiva, A. C. C. Quantidades e tempos de decomposição da flor-de-seda no desempenho do rabanete. Revista Verde de Agroecologia e Desenvolvimento Sustentável, v.6, p.168-173, 2011.

Linhares, P. C. F.; Silva, M. L.; Silva, U. L.; Silva, J. S.; Holanda, A. K. Velocidade e tempo de decomposição da jitirana incorporada na cultura do rabanete. Revista Caatinga, v.22, p.206-210, 2009.

Meurer, E. J. Fatores que influenciam o crescimento e o desenvolvimento das plantas. In: Novais, R. F.; Alvarez V., V. H.; Barros, N. F.; Fontes, R. L. F.; Cantarutti, R. B.; Neves, J. C. L. (ed.). Fertilidade do solo. Viçosa: SBCS, 2007. p.65-90. 
Oliveira, L. A. A.; Bezerra Neto, F.; Silva, M. L.; Oliveira, O. F. N.; Lima, J. S. S.; Barros Júnior, A. P. Viabilidade agronômica de policultivos de rúcula/cenoura/alface sob quantidades de flor-deseda e densidades populacionais. Revista Caatinga, v.28, p.116126, 2015. http://dx.doi.org/10.1590/1983-21252015v28n413rc

Santos, J. F.; Grangeiro, J. I. T.; Brito, L. M. P.; Oliveira, M. M.; Oliveira, M. E. C. Novas variedades de caupi para microrregião do Brejo Paraibano. Tecnologia \& Ciência Agropecuária, v.3, p.7-12, 2009.

Silva, M. G.; Sharma, R. D.; Junqueira, A. M. R.; Oliveira, C. M. Efeito da solarização, adubação química e orgânica no controle de nematóides em alface sob cultivo protegido. Horticultura Brasileira, v.24, p.489-494, 2006. http://dx.doi.org/10.1590/S010205362006000400019
Silva, M. L. da; Bezerra Neto, F.; Linhares, P. C. F.; Bezerra, A. K. H. Produção de cenoura fertilizada com flor-de-seda (Calotropis procera (Ait.) R.Br.). Revista Ciência Agronômica, v.44, p.732740, 2013. http://dx.doi.org/10.1590/S1806-66902013000400009

Silva, M. L. da; Bezerra Neto, F.; Linhares, P. C. F.; Sá, J. R.; Lima, J. S. S.; Barros Júnior, A. P. Produção de beterraba fertilizada com jitirana em diferentes doses e tempos de incorporação ao solo. Revista Brasileira de Engenharia Agrícola e Ambiental, v.15, p.801-809, 2011. http://dx.doi.org/10.1590/S1415-43662011000800006

Souza, E. G. F.; Barros Júnior, A. P.; Bezerra Neto, F.; Silveira, L. M.; Leal, Y. H.; Alves, M. J. G. Rentabilidade da rúcula fertilizada com biomassa de flor-de-seda em função da época de cultivo. Revista Caatinga, v.28, p.65-77, 2015. 